\title{
Red vent syndrome in wild Atlantic salmon Salmo salar in Scotland is associated with Anisakis simplex sensu stricto (Nematoda: Anisakidae)
}

\author{
Patricia Noguera ${ }^{1, *}$, Catherine Collins ${ }^{1}$, David Bruno ${ }^{1}$, Campbell Pert ${ }^{1}$, \\ Anna Turnbull ${ }^{1}$, Alison McIntosh ${ }^{1}$, Katherine Lester ${ }^{1}$, Ian Bricknell ${ }^{1,2}$, \\ Stuart Wallace ${ }^{1}$, Paul Cook ${ }^{1}$ \\ ${ }^{1}$ Marine Scotland, Marine Laboratory, PO Box 101, 375 Victoria Road, Aberdeen AB11 9DB, UK \\ ${ }^{2}$ Present address: School of Marine Sciences, University of Maine, Orano, Maine 04469, USA
}

\begin{abstract}
Simultaneous reports were received between June and July 2007 of wild Atlantic salmon Salmo salar with red, swollen, bloody vents returning to geographically diverse rivers in Scotland. By the end of September the condition, colloquially known as 'red vent syndrome' (RVS), was reported from $>50$ rivers across Scotland. Fish were generally in good overall condition but the vent area showed mild to severe lesions. External characteristics of the syndrome included a swollen, raised, haemorrhagic vent and surrounding tissues, with erosion of the skin, scale loss and moderate to severe bleeding in more advanced cases. Predominantly, the fish affected were 1-sea-winter grilse; however, RVS was also recorded in 2-sea-winter salmon and sea trout $S$. trutta. High numbers of the nematode Anisakis Type I larvae were found infesting the discrete region of the vent, a localisation that is reported as novel for the parasite. The hypothesis that this is a different species than that commonly found in the body cavity and viscera was investigated through molecular studies. These studies failed to show evidence that the parasites infesting the vent were different from those in the body cavity, i.e. all were identified as $A$. simplex sensu stricto. No other disease agent was found associated with the lesions or was isolated systemically, and no mortality or prevention of spawning was recorded during the 2007 season. Possible causes, including warming environments in the North Atlantic, are hypothesised as playing a role in the development of RVS in Atlantic salmon.
\end{abstract}

KEY WORDS: Atlantic salmon · Wild fish $\cdot$ Red vent syndrome $\cdot$ Anisakis simplex

\section{INTRODUCTION}

Atlantic salmon fishing is an important economic resource, with income generated largely through angling and associated tourism-generated jobs. The last official estimation of the annual income from salmon and sea-trout anglers in Scotland was £73.5 million, supporting an estimated 2200 full-time jobs, mostly in remote, rural areas (Scottish Executive 2004). Public and official concern about wild salmon health status was reflected as early as in the 1930s through studies commissioned by the UK government when the cause and impact of furunculosis was investigated (Mackie et al. 1933); this was followed by studies on 'Dee disease', known later as bacterial kidney disease (BKD), and by the mid 1960s, the condition termed ulcerative dermal necrosis (UDN) was also under investigation (Roberts 1993). It is often very difficult to quantify the effect of a pathogen on wild host populations, and historically, only a few conditions have been reported as causing conspicuous and significant disease epidemics in wild salmon stocks (Bakke \& Harris 1998). An example among parasites and probably the most significant in terms 
of impact is Gyrodactylus salaris (Johnsen \& Jensen 1991) affecting Norwegian wild salmon.

Records kept by Marine Scotland (formerly Fisheries Research Services) on wild fish surveys and statutory inspections show that since 2005 there have been sporadic reports of 'red vents' or 'bloody vents' in salmon returning to Scottish rivers. There are also anecdotal observations from anglers and gillies who have fished particular rivers for $>20 \mathrm{yr}$ stating that the condition has been consistently observed in the past but more frequently in recent years (D. Stewart pers. comm.) and that it peaked dramatically in 2007. Preliminary observations on red vent syndrome (RVS) in Scotland suggested that the condition was attributable to the presence of the nematode Anisakis spp. (Noguera et al. 2008), and Beck et al. (2008) reported similar observations in England and Wales, where the condition showed an increasing trend from $3 \%$ in 2005 , to $9 \%$ in 2006 and up to $27 \%$ in 2007 in trap-caught fish screened from River Dee in North Wales. Furthermore, RVS has been observed in salmon from Ireland, Norway and Canada (T. A. Mo pers. comm., H. Rodger pers. comm., G. Seguin pers. comm.). Recently, Iceland has also officially reported the condition (Helgason et al. 2008), and therefore RVS appears to be a feature of the entire North Atlantic region.

The genus Anisakis has a pan-global distribution and occurs in all marine environments (Davey 1971, Smith \& Wootten 1984). The identification of species within groups was historically done through morphology, but in the late 1980s it was recognised that morphology alone cannot accurately make identifications to the species leveli currently, taxonomic issues within the genus Anisakis are being further resolved through the development and application of genetic studies. This allowed the demonstration of 2 main clades of species sharing the larval morphology of Anisakis spp. Type I or Type II (sensu Berland 1961) (Orecchia et al. 1986, Mattiucci et al. 2005, Mattiucci \& Nascetti 2006, Valentini et al. 2006). Moreover, genetic markers from multilocus allozyme electrophoresis have shown that A. simplex (Davey 1971) falling in the first clade is a complex of sibling species comprising $A$. simplex sensu stricto (s.s.), A. pegreffii and A. simplex C (Nascetti et al. 1986, Mattiucci et al. 1997, D'Amelio et al. 2000, Mattiucci \& Nascetti 2006), They not only differ in their genetic structure, but also in their lifehistory and geographic distribution, with A. simplex s.s. being reported to be widespread between $35^{\circ} \mathrm{N}$ and the Arctic polar circle of both the western and eastern waters of both the Atlantic and the Pacific oceans, with a southern limit of the eastern North Atlantic in the waters of the Gibraltar area (Mattiucci et al. 1997, D'Amelio et al. 2000, Abollo et al. 2001, Mattiucci \& Nascetti 2006). The current taxonomy and ecology of the recognised species have been recently reviewed by Mattiucci \& Nascetti (2008).

The parasite has a complex life cycle involving marine mammals (especially cetaceans) as the final host, and fish, squid and planktonic crustaceans as paratenic or intermediate hosts harbouring the larval stages (Smith \& Wootten 1978, Mattiucci et al. 2004). Humans can also accidentally become infected by eating raw or undercooked seafood or cephalopods that contain the third-stage larvae (L3), which can be invasive, penetrating the host's stomach or intestinal wall and causing gastroenteric manifestations or inducing allergic reactions (Zaffiro et al. 2002). Among the roundworms that infect fish, members of the genus Anisakis are by far the most widespread and abundant parasite and are found in almost all commercially exploited species in North Atlantic waters (Smith \& Wootten 1978, Wootten \& Cann 1980). The larval worms (L3) penetrate the gut wall and normally encapsulate in the body cavity tissues and the external surfaces of the gut, pyloric caeca, liver and fat tissue, inducing a mild to moderate adhesion reaction in the host. However, they can also migrate and locate in the skeletal muscle thereby affecting the edible part of the fish (Smith \& Wootten 1984, Abollo et al. 2001). As a chronic infection Anisakis spp. does not result in mass mortality (Kent \& Fournie 1993). However, it is one of the most important parasitic problems for the fishing industry because it reduces the quality of the flesh and can have an impact on human health (zoonotic condition). Anisakis spp. are at the top of the list of pathogenic roundworms transmitted via seafood products (Audicana et al. 2002, Huss \& Embarek 2003).

The widespread nature and almost synchronised reporting of RVS prompted the present study, with the aims of investigating the aetiology of RVS and responding to questions on the possible impact on wild fish spawning and whether farmed fish were affected by the condition. Warming environments induced by climate variability in the North Atlantic is hypothesised as playing a role in the occurence of RVS.

\section{MATERIALS AND METHODS}

Geographical distribution. Reports received at the Marine Laboratory at Marine Scotland between late June and September 2007 were used to map the rivers or catchments areas reporting RVS-positive fish. The map was produced using the geographic information systems (GIS) software ESRI.

Sample collection. Between July and September 2007, 31 fish were collected for sampling purposes. Fifteen were caught using bag nets at Strathy Point (Sutherland), including 3 fish exhibiting normal vents 
for use as reference material. A further 12 fish were collected using a sweep net at the North Esk (Angus) upper estuarine fishery, and the remainder were provided by anglers, 2 from River Dee (Aberdeenshire), 1 from River Don (Aberdeenshire) and 1 from River Inver (Sutherland). Fish necropsy was generally completed on site, with collection of specific samples for haematological, virological, bacteriological, histopathological, parasitological and molecular analysis. Sampling date, origin, number of fish and sex are shown in Table 1.

Spawning success was further analysed in an additional 11 broodstock fish held at 3 different locations during the 2007 stripping season: the hatchery at River Don Mill of Newe, the Conon fish trap (managed by the District Salmon Fishery Board) and the River Dee trap at Baddoch (managed by the Marine Scotland, Freshwater Laboratory) (Table 1). Marine Scotland Fish Health Inspectorate (FHI) records of statutory testing on salmon sites were also analysed for any reported case of RVS- or Anisakis spp.-affected fish.

External examination. All fish were macroscopically examined and photographed prior to necropsy, and tissue was sampled at the point of capture, with the exception of those provided by anglers, which were received and sampled in the laboratory.

Photographs of the vent area were used to build a graphical key of the condition based on the lesions described and the tissues involved, and the RVSaffected fish were categorised as mild, moderate or severe (see Fig. 3).

For the purpose of this description, under the term 'vent' (specifically the external opening of the alimentary canal, the anus), we will refer to all tissues effectively involved in RVS: the vent and urogenital papilla, the genital cavity and pore, the last portion of the urinary canal, as well as the surrounding tissues of the

Table 1. Sampling date, origin, numbers and sex of analysed Salmo salar (bold: analysed for spawning success). R: river; nd: not determined; M: male; F: female; Gr: grilse

\begin{tabular}{|llcc|}
\hline $\begin{array}{l}\text { Date } \\
(\mathrm{dd} / \mathrm{md} / \mathrm{yy})\end{array}$ & Region & $\mathrm{n}$ & $\mathrm{Sex}$ \\
\hline $03 / 07 / 07$ & Strathy Point & 1 & nd \\
$25 / 07 / 07$ & Strathy Point & 1 & $\mathrm{M}$ \\
$28 / 07 / 07$ & R Dee/Banchory & 1 & nd \\
$02 / 08 / 07$ & Strathy Point & 13 & $4 \mathrm{M}, 1 \mathrm{~F}, 8 \mathrm{nd}$ \\
$13 / 08 / 07$ & R North Esk & 6 & $2 \mathrm{~F}, 4 \mathrm{M}$ \\
$14 / 08 / 07$ & R North Esk & 6 & 1 F Gr, 1 F, 4 M \\
$04 / 09 / 07$ & R Inver & 1 & nd \\
$15 / 09 / 07$ & R Dee/Maryculter & 1 & nd \\
$29 / 09 / 07$ & R Don & 1 & $\mathrm{M}$ \\
$06 / 11 / 07$ & R Dee/Baddoch & $\mathbf{1}$ & $\mathbf{F}$ \\
$22 / 11 / 07$ & R Mill of Newe & $\mathbf{5}$ & $\mathbf{F}$ \\
$27 / 11 / 07$ & R Conon/Hatchery trap $\mathbf{5}$ & $\mathbf{3 ~ F , ~ 2 ~ M ~}$ \\
& & & \\
\hline
\end{tabular}

posterior abdominal wall, abdominal pores and the skin and underlying adipose and muscle layers in the immediate area.

Blood smears. Caudal-vein blood samples were collected from Strathy Point and North Esk fish using Vacuette tubes (Greiner Bio-One). Blood smears were prepared on site, air-dried and transported to the laboratory, where they were Giemsa-stained and screened for evidence of blood-born parasites, bacterial infection and the presence of erythrocytic inclusion bodies.

Bacteriology and virology. For bacteriological assessment, an inoculum from kidney, vent lesion and hindgut was streaked onto blood agar (BA; Oxoid), trypticase soy agar (TSA; Oxoid), TSA plus $1.5 \% \mathrm{NaCl}$ (Oxoid), Müller-Hinton agar (MHCA; Difco) with $0.1 \%$ L-cysteine added during preparation and Anacker \& Ordal agar (A\&O) prepared in the laboratory using $0.5 \%$ tryptone (as modified by Lorensen 1993). Plates were incubated at $15^{\circ} \mathrm{C}(\mathrm{A} \& \mathrm{O})$ or $22^{\circ} \mathrm{C}(\mathrm{TSA}, \mathrm{TSA}+$ $\mathrm{NaCl}, \mathrm{MHCA}$ ) and checked for growth daily for $7 \mathrm{~d}$ or up to $12 \mathrm{wk}$ for MHCA. Imprints from the kidney and the vent lesion were also taken, air-dried and transported to the laboratory, where they were Gramstained and examined microscopically for bacterial and rickettsial agents.

For virological assessment, tissue samples were aseptically dissected, and pooled material from the head kidney, spleen, heart and encephalon from each fish were collected into separate viral transport medium tubes with Leibovitz-15 buffered medium with 10\% newborn calf serum plus antibiotics (gentamicin, polymyxin B and penicillin/streptomycin); $\mathrm{pH}$ was adjusted to 7.4 through the addition of $1 \mathrm{M} \mathrm{NaOH}$. Samples were homogenised and clarified by sedimentation and inoculated into TO, BF-2, FHM, CHSE-214 and E11 cell lines. Cultures were incubated at $15^{\circ} \mathrm{C}$ for 7 to $14 \mathrm{~d}$ and were checked for cytopathic effects (CPE) at the end of the incubation period. All cultures were subcultivated to fresh cells with a further 7 to $14 \mathrm{~d}$ incubation period depending on cell line and read microscopically for CPE at the end of this period (OIE 2006).

Molecular viral detection. RNA was extracted from kidney and vent tissue sampled in RNAlater (Ambion) using the MagAttract RNA Tissue Mini M48 kit and the BioRobot M48 extraction workstation (Qiagen). Tissues were screened for the presence of alphavirus using a previously described method (Hodneland \& Endresen 2006). Briefly, cDNA was generated using TaqMan Reverse Transcription Reagents according to the manufacturer's instructions (Applied Biosystems). Real-time PCR was performed in a $20 \mu$ final volume containing $1 \mu \mathrm{l}$ cDNA, $1 \times$ SensiMix Buffer (Quantace), $2.5 \mathrm{mM} \mathrm{MgCl}_{2}, 0.02$ units uracil-N-glycosylase (UNG), $0.9 \mu \mathrm{M}$ of each primer and $0.25 \mu \mathrm{M}$ probe on an $\mathrm{ABI}$ 7000 real-time PCR machine. 
Molecular parasite identification. Nematodes removed from the body cavity and vent tissue were stored in $100 \%$ ethanol. The parasite's outer coating was removed to reduce host-tissue contamination prior to DNA extraction using the DNeasy Tissue Kit (Qiagen) or by direct tissue lysis (Cunningham et al. 2001). Internal transcribed spacer ribosomal DNA (ITSrDNA) was amplified as described (Zhu et al. 1998), and the resultant PCR products were purified by MinElute Gel Purification (Qiagen) and sequenced on a CEQ 8800 using the GenomeLab DTCS Quick Start kit (Beckman Coulter). Restriction fragment length polymorphism (RFLP) analysis was performed on purified ITS PCR products using HinfI and HhaI (D'Amelio et al. 2000, Abollo et al. 2003, Pontes et al. 2005, Umehara et al. 2007). PCR products were cloned using the TOPO TA cloning vector (Invitrogen). Partial cytochrome oxidase I ( $\operatorname{cox} 1)$ mitochondrial DNA (mtDNA) was also amplified and sequenced from a subset of nematodes as described in Cross et al. (2007).

Anisakid ITS rDNA and cox1 sequences were aligned using Bioedit vers. 7.0.5.3 (Hall 1999). Phylogenetic relationships of $\operatorname{cox} 1$ sequences were determined using PAUP (vers. 4.0B10; Swofford 1999) and maximum-likelihood (ML) analysis with likelihood parameters determined by ModelTest (Posada \& Crandall 1998). Support for relationships was tested using neighbor-joining (NJ) analysis (ML settings) and 1000 replicates.

Nematodes from 2 clinically affected salmon were analysed with the purpose of comparison between body cavity and vent larvae. Four and 20 parasites from the vent area and 2 and 20 from the body cavity from each fish respectively were analysed by ITSRFLP. ITS and Cox1 regions were sequenced from 14 and 6 vent nematodes and 12 and 6 body cavity nematodes respectively.

Histology. Samples from all 42 fish were taken for histopathological assessment by light microscopy. Tissues were fixed in $10 \%$ neutral buffered formalin for 24 to $48 \mathrm{~h}$, and later trimmed, routinely processed and paraffin-embedded. Sections of 3 to $4 \mu \mathrm{m}$ were routinely stained with haematoxylin and eosin (H\&E), periodic acid-Schiffs (PAS) and Giemsa. Parasites in tissue sections were identified as nematodes by observing the multilayered acellular cuticle, lateral chords and pseudocoelom, according to Bruno et al. (2006).

Parasitology. For parasitological analysis, pieces of foregut, hindgut and vent tissue were fixed in 100\% ethanol and any parasites were later dissected from the tissue. Individual nematodes were also removed from body cavity viscera and in all cases they were analysed and identified morphologically after Berland (1961) and using keys from Moravec (2004).

\section{RESULTS}

The earliest Marine Scotland records describing a 'red swollen vent' on wild Atlantic salmon were found in 3 routine diagnostic cases from 2005, followed by one in 2006 during a statutory visit, though no specific samples were taken from these cases. During 2007, the simultaneous observations from all across Scotland resulted in the analysis of RSV distribution and targeted sample collection.

\section{Geographical distribution}

Between late June and the end of September 2007 a total of 59 rivers or catchment areas across Scotland were reported positive for RVS. The geographical distribution is presented in Fig. 1. All fish collected at Strathy Point were from the sea, and those from the North Esk had just returned from the sea into freshwater. Both male and female Atlantic salmon were represented among the analysed fish. It should be stressed that this only represents sample sex distribution, as the fish analysed for the purpose of the present study will not be suitable for any extrapolation, due to potential biases in sampling, with some cases originating from angling and the majority being a subsample of a larger, non-assessed stock (Table 1).The laboratories' records show that no farmed salmon sites registered any case of fish affected by the syndrome or any similar condition affecting the vent area, so no evidence was found of RVS affecting farmed salmon.

\section{Gross observations}

The fish displaying signs of RVS were primarily 1sea-winter grilse weighing between 2 and $4 \mathrm{~kg}$, although 2 reports of 2-sea-winter Atlantic salmon Salmo salar and a single sea trout $S$. trutta were also recorded. The only external lesions observed were erythema due to the grazing action of sea lice around the anal fin and the swollen, haemorrhagic area around the vent and urogenital papilla (Fig. 2a). Mildly affected fish showed a generalised reddening around the vent and urogenital openings, sometimes with discrete petechial haemorrhage but limited swelling of the area (Fig. 3a); the moderate stage comprised a more widespread erythema in the surrounding 25 to $30 \mathrm{~mm}$ area with associated mild swelling, with conspicuous foci of petechial haemorrhage and scale lifting (Fig. 3b). The severe stage of the condition comprised a marked protrusion of the vent area, with generalised haemorrhage and swelling, and breakdown of the skin surface, scale loss and bleeding (Fig. 3c). 


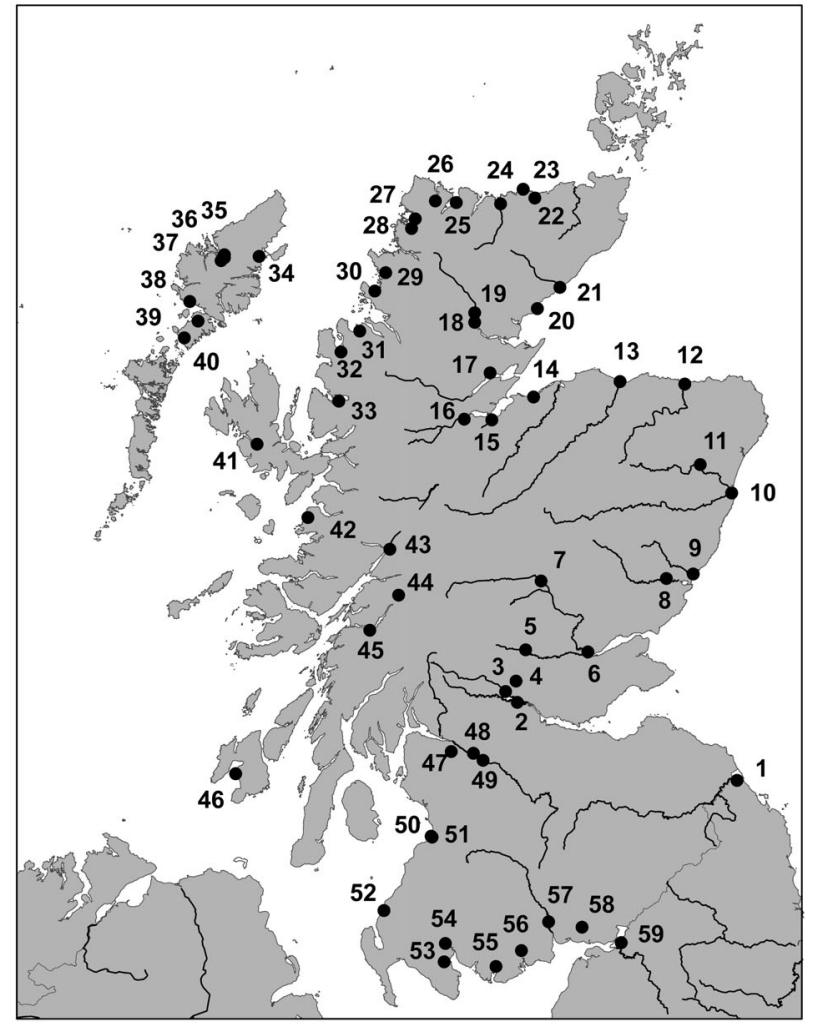

Fig. 1. Distribution of reported red vent syndrome (RVS)affected rivers or catchments areas in Scotland during the period June to November 2007. 1, Tweed; 2, Forth; 3, Teith; 4, Allan; 5, Earn; 6, Tay; 7, Loch Faskally; 8, Esk (South); 9, Esk (North); 10, Dee (Aberdeenshire); 11, Don; 12 Deveron; 13, Spey; 14, Nairn; 15, Ness; 16, Beauly; 17, Averon; 18, Oykel; 19, Shin; 20, Brora; 21, Helmsdale; 22, Hallidale Burn; 23, Strathy Point (netting station); 24, Naver; 25, Hope; 26, Dionard; 27, Rhiconich; 28, Laxford; 29, Inver; 30, Garvie; 31, Gruniard; 32, Ewe; 33, Balgy; 34, Abhainn Ghrioda; 35, Gearraidh na h-Aibhne; 36, Abhainn Dhubh; 37, Abhainn Ghriomarstaidh; 38, Abhainn Eabhal; 39, Abhainn Lacasdail; 40, Loch Moracha; 41, Drynoch; 42, Morar; 43, Lochy; 44, Etive; 45, Awe; 46, Lagan; 47, Gryfe; 48, Kelvin; 49, Clyde; 50, Ayr ; 51, Doon; 52, Stinchar; 53, Bladnoch; 54, Cree; 55, Dee (Kirkcudbrightshire); 56, Urr; 57, Nith; 58, Annan; 59, Esk (Border)

All fish were found to be in generally good external condition, and a moderate to high fat storage in the body cavity could be observed at necropsy in all fish. Some fish showed signs of recent feeding, though most did not, as confirmed through empty guts and enlarged gall bladders. Fish analysed had low to moderate numbers of nematode larvae within the body cavity, around the pyloric caeca-pancreas and on the liver surface, but parasites were not obvious from the stomach to the end of body cavity (Fig. 2b). Those fish with swollen vents also had numerous larvae aggregated within the discrete region of the vent-urogenital papilla, and on some occasions, parasites could be seen with the naked eye at the surface of the vent through the transparent scales (Fig. 4a). When the skin was carefully dissected and lifted, several larvae were observed right underneath the tegument between the hindgut and the skin (Fig. 4b). Parasite burden could be very large on symptomatic fish, with a count of $>100$ larvae within the vent region from a single salmon dissected ad hoc.

\section{Histology}

All fish with mild, moderate or severe lesions as well as 2 of the reference normal fish harboured nematode larvae in the vent region. Summer estuarine fish from Strathy Point and the North Esk showed capillary dilation, blood congestion, haemorrhage and moderate to severe inflammation (Fig. 5), dominated by eosinophilic granular cells (EGCs) (Fig. 6), melanomacrophages and occasionally, multinucleated giant cells (Fig. 7), mostly associated with non-encapsulated parasites. EGCs decreased to very low numbers or were absent in fish sampled several months later in freshwater (spawned autumn fish). These fish showed predominantly encapsulated larvae within a granulomatous connective tissue reaction (Fig. 8) and increase in melanin-containing cells (both melanomacrophages and melanophore-like cells) (Fig. 9). Degeneration of encapsulated larvae associated with necrosis and inflammatory reaction was occasionally observed (Fig. 10). The epidermis of severely affected summer fish could be absent or largely detached from the basal membrane, while autumn fish showed a completely healed epidermal layer. The dermal layer of both summer and autumn fish harboured a number of larvae, and was seen infiltrated and haemorrhagic in the early summer fish, while in the autumn fish, this region was thickened due to reparative processes with some inflammatory cells and regenerative scales (Fig. 11). Parasite larvae were localised immediately outside the terminal portion of the hindgut (rectum), ventro-laterally in the discrete space towards the skin, between the hindgut and the genital canal/cavity (depending on the section level), between the genital cavity and the urethra, and dorso-laterally to the urogenital ducts deep within the skeletal musculature (Fig. 11). Inflammatory reaction, when seen in this latter location, was apparently less severe. Non-encapsulated larvae were occasionally seen within the lumen of the genital cavity of the recently spawned fish (Fig. 12). Capillary congestion and surrounding increased free blood was observed, likely as a result of the assisted stripping process.

Most fish examined also had larvae on the liver surface and encysted around the spleen and the stomach wall with an associated moderate adhesion reaction. 

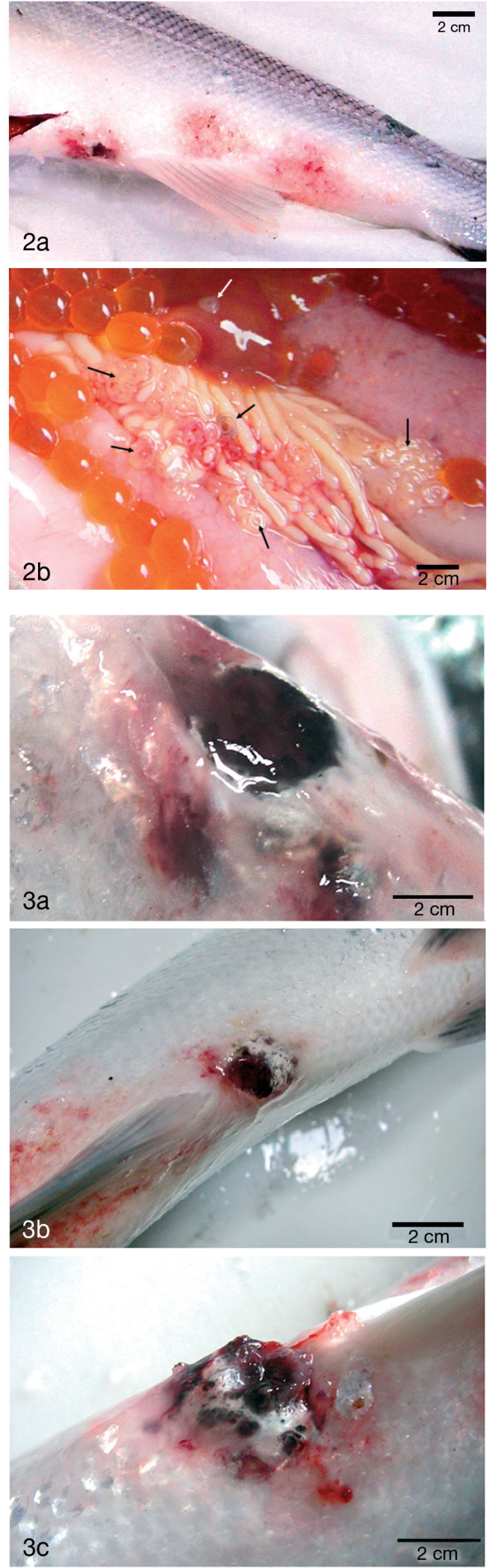
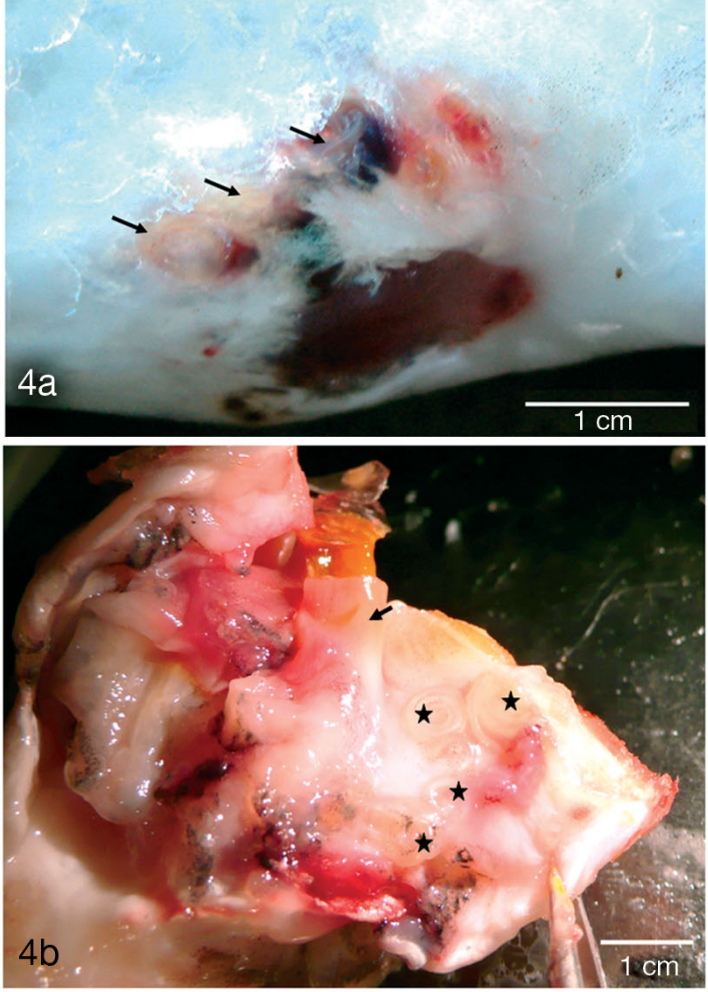

Figs. 2 to 4 . Salmo salar affected by red vent syndrome (RVS). Fig. 2. (a) Typical external observations of fish from estuarine $\overline{\text { waters }}$ and (b) internal aspect of a freshwater autumn fish. Note larvae (arrows) on liver, stomach and around the pyloric caeca. Fig. 3. Graphical key of RVS condition based on lesions described and tissues involved: (a) mild, (b) moderate and (c) severe. Fig. 4. Parasite larvae could occasionally be seen with the naked eye even in fish not severely affected. (a) Larvae (arrows) just at the surface of the vent. (b) With tegument lifted, numerous larvae $(\star)$ seen between hindgut (arrow) and directly underneath the skin

EGCs were increased in the lamina propria and also widespread in the gills and bulbus arteriosus of summer fish (Fig. 13). Gill EGCs were seen surrounding the lamellar rod, de-granulating and inducing an apparent re-absorption of the cartilage. EGCs dropped to almost zero in tissues from the autumn fish. Other observations included one fish with a cestode within the gut lumen and another one with protozoans in the kidney tubules. All other tissues were within the normal range, i.e. none of the fish showed a systemic compromise of any of the organs normally targeted in infectious disorders, including the kidney, liver, spleen, gut mucosa, pancreas and heart.

\section{Microbiology, haematology and parasitology}

Isolates from the hindgut reflected abundant normal gut flora with no differences between those from fish with or without vent lesions. No bacteria were ob- 

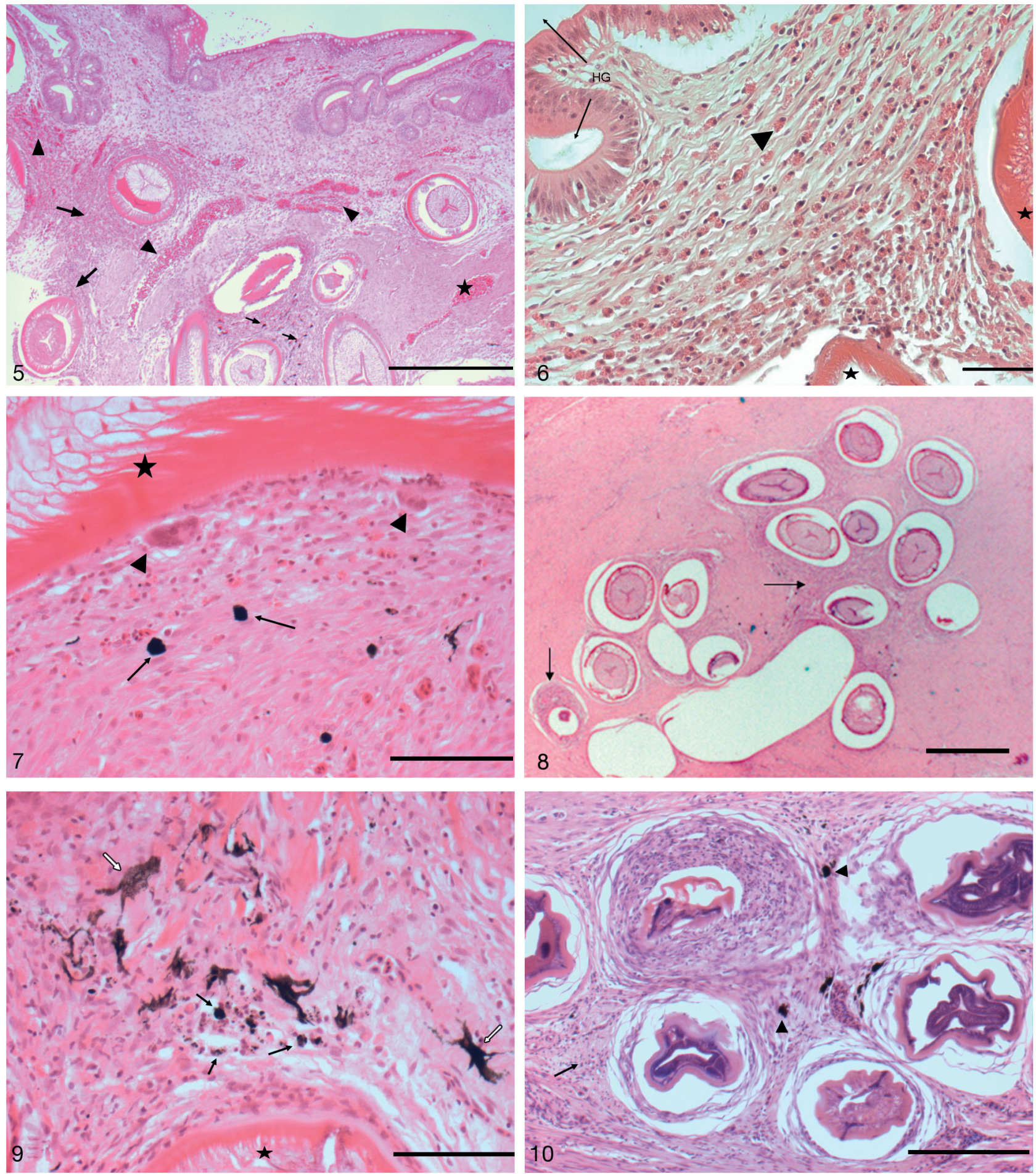

Figs. 5 to 10. Salmo salar affected by red vent syndrome. Fig. 5. Capillary dilation, blood congestion ( $\star$ ), haemorrhage (arrowheads) and inflammation (large arrows). Melanomacrophages are also present (small arrows). H\&E. Scale bar $=500 \mu m$. Fig. 6. Inflammation massively dominated by an influx of eosinophilic granular cells (EGCs) (arrowhead) in the summer fish. Parasite larvae $(\star)$, hindgut (HG). H\&E. Scale bar $=100 \mu \mathrm{m}$. Fig. 7. Melanomacrophages (arrows) and multinucleated giant cells (arrowheads) associated with non-encapsulated parasites $(\star)$. H\&E. Scale bar $=100 \mu \mathrm{m}$. Fig. 8. Granulomatous tissue reaction encapsulating the larvae (arrows). Scale bar $=500 \mu \mathrm{m}$. Fig. 9. Melanin-containing cells: melanomacrophages (arrows) and melanophore-like cells (white arrows). Parasite larvae $(\star)$. $\bar{H} \&$ E. Scale bar $=100 \mu \mathrm{m}$. Fig. 10. Necrosis and inflammatory reaction (arrow) associated with degenerative parasite larvae (see melanomacrophages; arrowheads). H\&E. Scale bar $=200 \mu \mathrm{m}$ 

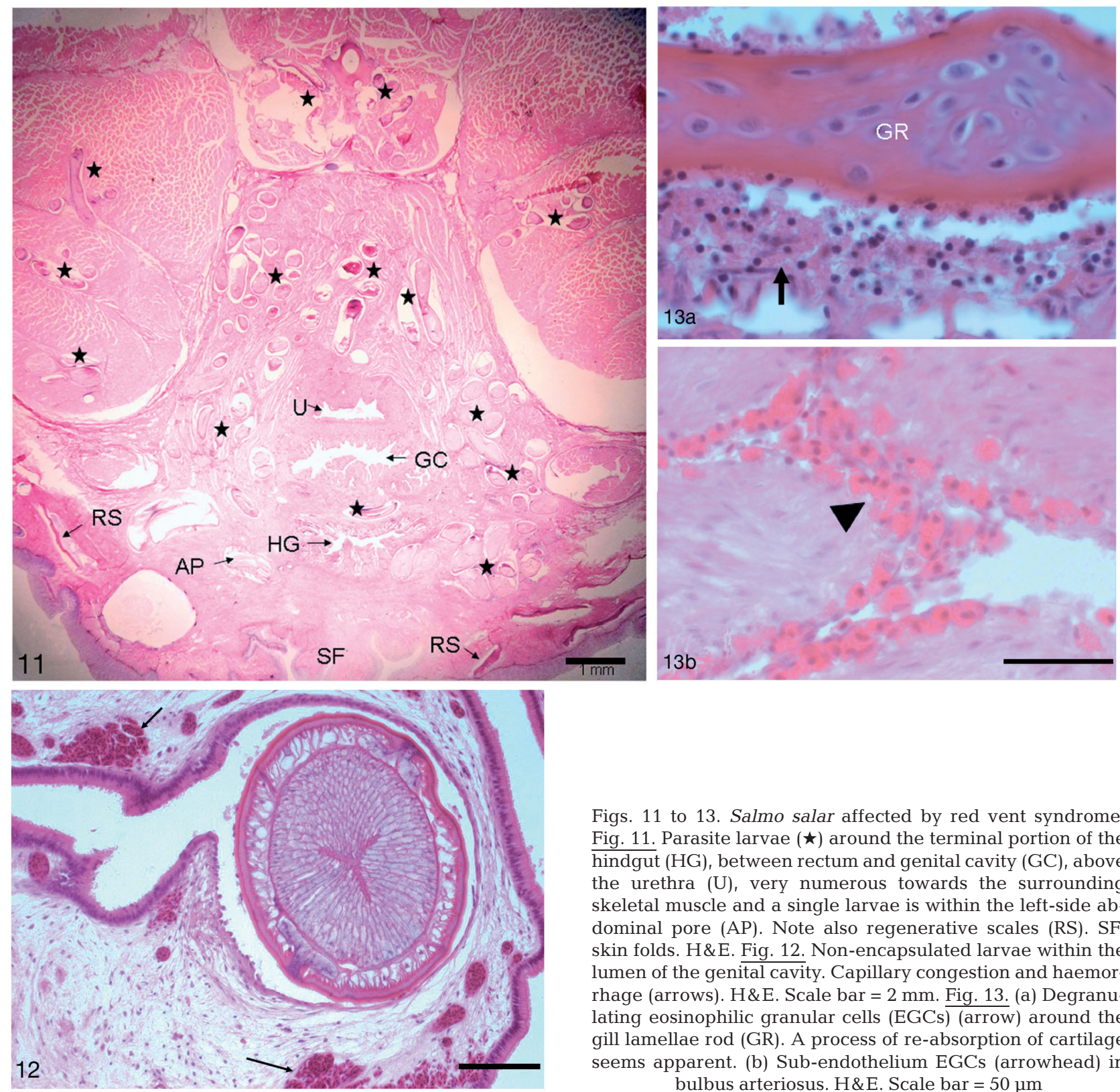

Figs. 11 to 13. Salmo salar affected by red vent syndrome. Fig. 11. Parasite larvae $(\star)$ around the terminal portion of the hindgut (HG), between rectum and genital cavity (GC), above the urethra (U), very numerous towards the surrounding skeletal muscle and a single larvae is within the left-side abdominal pore (AP). Note also regenerative scales (RS). SF: skin folds. H\&E. Fig. 12. Non-encapsulated larvae within the lumen of the genital cavity. Capillary congestion and haemorrhage (arrows). H\&E. Scale bar $=2 \mathrm{~mm}$. Fig. 13. (a) Degranulating eosinophilic granular cells (EGCs) (arrow) around the gill lamellae rod (GR). A process of re-absorption of cartilage seems apparent. (b) Sub-endothelium EGCs (arrowhead) in bulbus arteriosus. H\&E. Scale bar $=50 \mu \mathrm{m}$

served in either Gram-stained vent-tissue smears or Giemsa-stained slides, which correlated with the negative culture results.

Virological testing as well as bacterial cultures from kidney and vent tissue were also negative for all notifiable disease agents.

The examination of blood smears was negative for blood-borne parasites and erythrocytic inclusion bodies.

The majority of nematode larvae collected were alive and displaying motility, and measured between 10.2 and $20.2 \mathrm{~mm}$ in length. Larvae were identified morphologically as Anisakis Type I larvae (sensu Berland 1961). Some fish had a few parasites identified as Hysterothylacium gadi aduncum (Moravec 2004) in the posterior hindgut.

\section{Molecular analysis}

Molecular analysis identified the Anisakis spp. larvae from both cavity and vent as $A$. simplex s.s., based on HinfI and HhaI RFLP patterns (Fig. 14) (D'Amelio et al. 2000) and sequence data. RFLP patterns were identical for all parasites from both vent and cavity. A faint band at approximately $700 \mathrm{bp}$ in the HinfI digest was observed in all samples from vent and cavity, and 

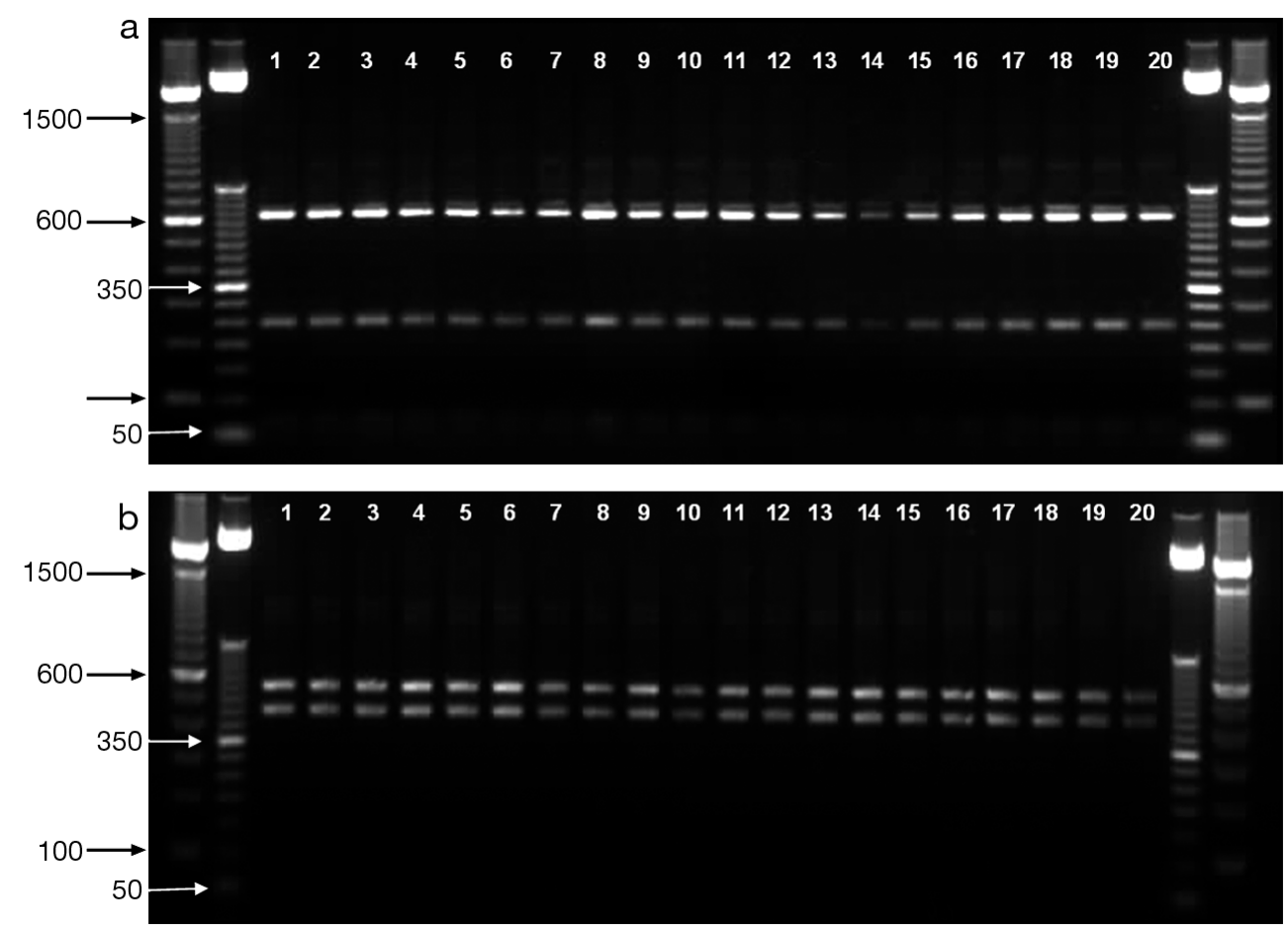

Fig. 14. (a) HinfI and (b) HhaI internal transcribed spacer-restriction fragment length polymorphism (ITS-RFLP) patterns of Anisakis spp. parasites collected from vent tissue (Lanes 1 to 10) and cavity (Lanes 11 to 20) of Atlantic salmon displaying red vent syndrome

may represent incomplete digestion. All Anisakis spp. specimens sequenced had nucleotides (GenBank accession no. GQ143710) identical to that of A. simplex s.s. (AY826723; D'Amelio et al. 2000) at those positions which vary between the ITS of known species (AB196671, AB277822, AJ937669, AY821738, AY821739, AY821740, AY821749), apart from 3 specimens which displayed a $\mathrm{C} / \mathrm{T}$ heterogeneity at position 305 (GQ143709) and a single specimen which displayed a $\mathrm{C} / \mathrm{T}$ heterogeneity at position 305 and also at position 173 (GQ143711). A. simplex s.s. AY826723 has a T at position 305 , while some other species, including $A$. simplex $C$ and $A$. pegreffii have a $C$. These 4 specimens displaying heterogeneity originated from both vent $(\mathrm{n}=3$ ) and cavity $(\mathrm{n}=1)$; all specimens displayed heterogeneity at position $791(\mathrm{C} / \mathrm{T})$. All nucleotide positions are given relative to the sequence for AY826723. The heterogeneity observed in sequenced PCR products was confirmed for positions 173 and 305 by sequencing of cloned products, but not for position 791, where all 4 clones analysed contained a C. The observed heterogeneity at position 791 may represent a sequencing artefact. Cloned ITS sequence contained $\mathrm{C}$ and $\mathrm{T}, \mathrm{T}$ and $\mathrm{T}$ and $\mathrm{C}$ and $\mathrm{C}$ at positions 173 and 305 respectively. A $\mathrm{T}$ and $\mathrm{C}$ variant was not observed. Based on alignment of available sequences from GenBank, the heterogeneity observed in the present study did not represent potential hybrids of known anisakid species with respect to displaying polymorphism at all species-diagnostic sites. However, sequences from 2 A. simplex specimens infecting herring Clupea harengus membras in the Baltic Sea (AJ937670/71) displayed $\mathrm{T}$ at position 173, and a specimen from Baltic Sea cod displayed C/T (AJ225065) at this position. These sequences did not show polymorphisms corresponding to position 305 as seen in some Anisakis spp. specimens analysed from RVS-affected salmon. Recently an ITS rDNA sequence from A. simplex infecting onion-eye grenadier Macrourus berglax from the east coast of Greenland was submitted to GenBank (GQ131690). This sequence had $\mathrm{N}$ at position 173 and $\mathrm{Y}$ at position 305. An overview of ITS rDNA sequence variation in A. simplex is given in Fig. 15.

Twelve different cox1 haplotypes were obtained, differing from each other by 3 to 15 nucleotides over a region 955 nucleotides in length (GQ132122 to GQ132133). No consistent differences or groups associated with vent or cavity sampling site, or with the presence of polymorphisms in the ITS rDNA were observed, neither by visual examination of the aligned sequences nor following phylogenetic analysis. Most variation consisted of nucleotide polymorphisms confined to individuals. Two positions showed a consistent difference between the anisakids analysed from 


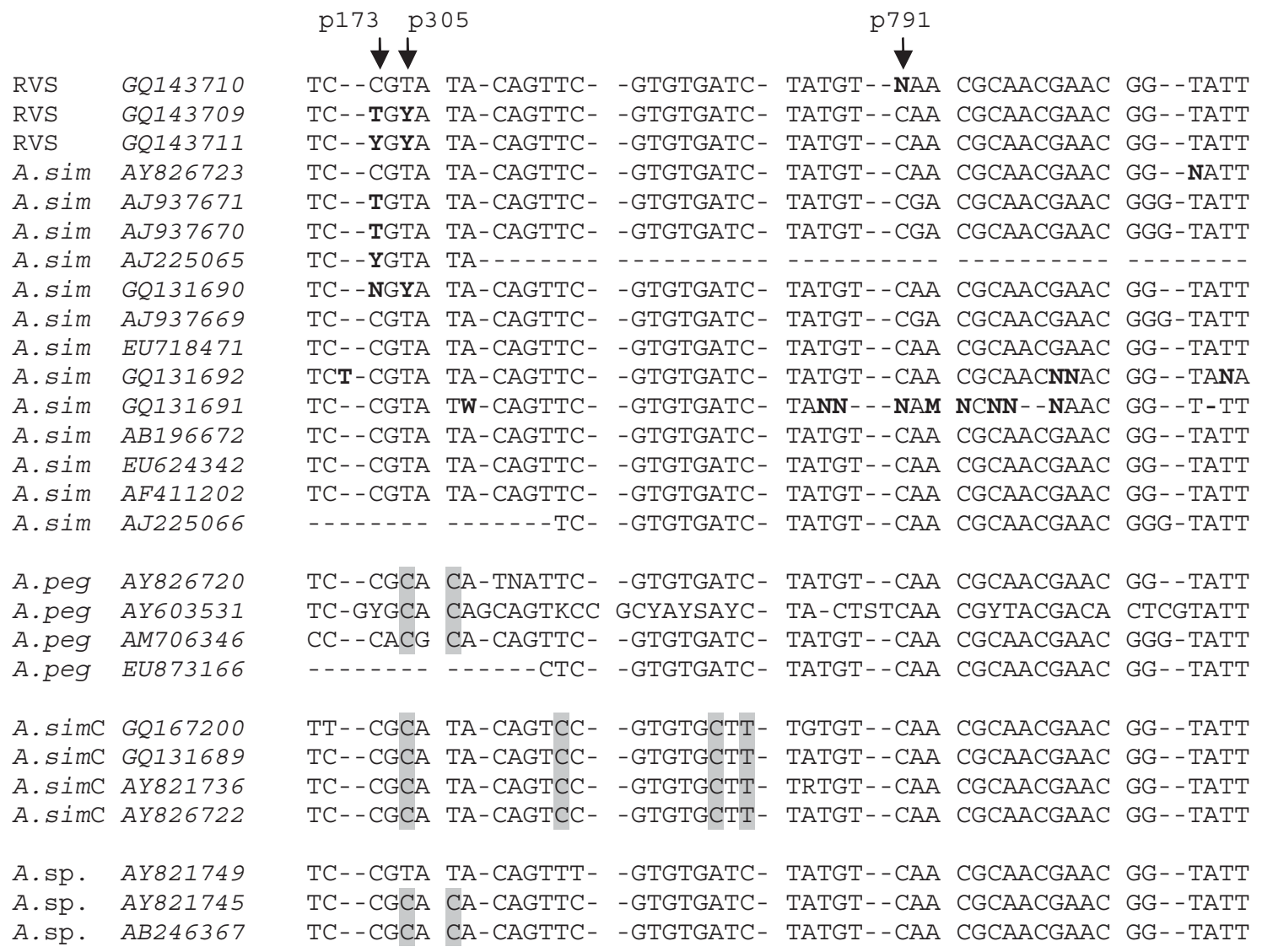

Fig. 15. Alignment of internal transcribed spacer ribosomal DNA (ITS rDNA) sequences from Anisakis spp. Nucleotide positions conserved across all sequences have been removed. Nucleotides differing between sequences reported as $A$. simplex (A. sim) are in bold. Positions (p) 173 and 305, which displayed heterogeneity in Anisakis spp. specimens from salmon with red vent syndrome (RVS), are indicated. Nucleotide positions that differ consistently between different Anisakis spp. and A. simplex s.s. are highlighted in grey. A. peg: A. pegreffii, A. simC: A. simplex 'C', A. sp.: uncharacterised Anisakis species

salmon with RVS in the present study, and cox1 from Anisakis simplex s.s. infecting herring populations around the British Isles (Cross et al. 2007). These nucleotide differences translated to differences at the amino acid level. A number of differences were observed with cox1 from A. pegreffii (Fig. 16).

\section{DISCUSSION}

Although the greatest diversity of parasites in Atlantic salmon Salmo salar are known from their marine phase, few are likely to be of pathogenic significance. Conclusive evidence is lacking though, as parasitised salmon cannot be readily identified and tracked (Bakke \& Harris 1998). The present investigation into abnormal, haemorrhagic vents in returning wild Atlantic salmon showed that the discrete region of the vent and urogenital papilla is affected by a parasite-induced condition associated with the presence of high numbers of Anisakis simplex s.s. larvae. No bacterial, viral or fungal pathogen was found to be associated with the condition. The distribution, covering virtually all Scottish salmon rivers and catchment areas

Fig. 16. Alignment of partial anisakid cytochrome oxidase I (cox1) mitochondrial putative protein sequence. RVS: anisakids isolated from salmon displaying red vent syndrome (present study). C: cavity, V: vent. * ${ }^{*}$ cox1 sequence representative of individuals showing polymorphism in their internal transcribed spacer ribosomal DNA (ITS rDNA) sequence (cox1 accession no./ITS accession no.: ${ }^{\mathrm{a}} \mathrm{GQ132130/GQ143711,} \mathrm{b} \mathrm{GQ132123/GQ143709,}{ }^{\mathrm{C}} \mathrm{GQ132122/GQ143709).} \mathrm{H/BI:} \mathrm{cox1} \mathrm{sequence} \mathrm{data} \mathrm{from} \mathrm{anisakids} \mathrm{in-}$ fecting herring around the British Isles. Cross H/BI: cox1 sequence representing 153 anisakid individuals from herring around the British Isles (Cross et al. 2007). AY994157 C. my: Anisakis simplex cox1 from individual infecting Conger myriaster (Kim et al. 2006). A. sim: A. simplex, A. peg: A. pegreffii. Amino acids differing from consensus type are highlighted in black (RVS anisakids), dark grey (H/BI anisakids) and light grey (A. pegreffii) 
RVS $\operatorname{cox} 1 C \star^{\mathrm{a}}(5) \mathrm{V} \star^{\mathrm{b}}(4)$ RVS COx1 C GQ132133 RVS COx1 V GQ132127 RVS COx $1 V^{*}{ }^{\mathrm{C}} \mathrm{GQ132122}$ A.sim DQ994401 H/BI A.sim DQ994375 H/BI A.sim DQ994333 H/BI A.sim DQ994391 H/BI A.sim DO994356 H/BI A.sim DQ994353 H/BI A.sim DQ994243 H/BI A.sim DQ994325 H/BI A.sim Cross H/BI A.sim AY994157 C.mY A.peg FJ907317

RVS $\operatorname{cox} 1 \quad C \star^{\mathrm{a}}(5) \mathrm{V} \star^{\mathrm{b}}(4)$ RVS COx1 C GQ132133 RVS Cox1 V GQ132127 RVS COx1 V* GQ132122

A.sim DQ994401 H/BI A.sim DQ994375 H/BI A.sim DQ994333 H/BI A.sim DQ994391 H/BI A.sim DQ994356 H/BI A.sim D0994353 H/BI A.sim DQ994243 H/BI A.sim DQ994325 H/BI A.sim Cross H/BI A.sim AY994157 C.mY A.peg FJ907317

RVS $\operatorname{cox} 1 C *^{\mathrm{a}}(5) \mathrm{V} *^{\mathrm{b}}(4$ RVS COX1 C GQ132133 RVS COX1 V GQ132127 RVS COx1 V* $*^{\mathrm{c}}$ GO13212

A.sim DQ994401 H/BI A.sim DQ994375 H/BI A.sim DQ994333 H/BI A.sim DQ994391 H/BI A.sim DQ994356 H/BI A.sim DQ994353 H/BI A.sim DQ994243 H/BI A.sim DO994325 H/BI A.sim Cross H/BI A.sim AY994157 C.mY A.peg FJ907317

RVS Cox $1 \quad \mathrm{C}^{*^{\mathrm{a}}}(5) \mathrm{V} *^{\mathrm{b}}(4$ RVS COx1 C G0132133 RVS COx1 V GQ132127 RVS COX1 V* GQ132122 A.sim D0994401 H/BI A.sim DQ994375 H/BI A.sim DQ994333 H/BI A.sim DQ994391 H/BI A.sim DQ994356 H/BI A.sim DQ994353 H/BI A.sim DQ994243 H/BI A.sim DO994325 H/BI A.sim Cross H/BI A.sim AY994157 C.mY A.peg FJ907317

RVS $\operatorname{cox} 1 C *^{\mathrm{a}}(5) \mathrm{V} *^{\mathrm{b}}(4)$ RVS COx1 C GQ132133 RVS COx1 V GQ132127 RVS COx1 V*C GQ132122 A.sim DQ994401 H/BI A.sim DQ994375 H/BI A. sim DQ994333 H/BI A.sim DQ994391 H/BI A.sim DQ994356 H/BI A.sim DQ994353 H/BI A.sim DQ994243 H/BI A.sim DQ994325 H/BI A.sim Cross H/BI A.sim AY994157 C.my A.peg FJ907317
VMPTMIGGFG NWMLPLMLGA PDMSCPRLNN LSFWLLPTAM FLILDSCFVD MGSGTSWTIY VMPTMIGGFG NWMLPLMLGA PDMSCPRLNN LSFWLLLTAM FLILDSCFVD MGSGTSWTIY 60 VMPTMIGGFG NWMLPLMLGA PDMSCPRLNN LSFWLLPTAM FLILDSCFVD MGSGTSWTIY 60 VMPTMIGGFG NWMLPLMLGA PDMSCPRLNN LSFWLLPTAM FLILDSCFVD MGSGTSWTIY 60 VMPTMIGGFG NWMLPLMLGA PDMSFPRLNN LSFWLLPTAM FLILDSCFVD MGSGTSWTIY 60 VMPTMIGGFG NWMLPLMLGA PDMSFPRLNN LSFWLLPTAM FLILDSCFVD MGSGTSWTIY 60 VMPTMIGGFG NWMLPLMLGA PDMSFPRLNN LSFWLLPTAM FLILDSCFVD MGSGTSWTIY 60 VMPTMIGGFG NWMLPLMLGA PDMSFPRLNN LSFWLLPTAM FLILDSCFVD MGSGTSWTIY 60 VMPTMIGGFG NWMLPLMLGA PDMSFPRLNN LSFWLLPTAM FLILDSCFVD MGSGTSWTIY 60 VMPTMIGGFG NWMLPLMLGA PDMSFPRLNN LSFWLLPTAM FLILDSCFVD MGSGTSWTIY 60 VMPTMIGGFG NWMLPLMLGA PDMSFPRLNN LSFWLLPTAM FLILDSCFVD MGSGTSWTIY 60 VMPTMIGGFG NWMLPLMLGA PDMSFPRLNN LSFWLLPTAM FLILDSCFVD MGSGTSWTIY 60 VMPTMIGGFG NWMLPLMLGA PDMSFPRLNN LSFWLLPTAM FLILDSCFVD MGSGTSWTIY 60 VMPTMIGGFG NWMLPLMLGA PDMSFPRLNN LSFWLLPTAM FLILDSCFVD MGSGTSWTIY 60 VMPTMIGGFG NWMLPLMLGA PDMSFPRLNN LSFWLLPTAM FLILDSCFVD MGSGTSWTVY 60

PPLSTMGHPG SSVDLAIFSL HSAGVSSILG AINFMTTTKN LRSSSISLEH MSLFVWTVFV 120 PPLSTMGHPG SSVDLAIFSL HSAGVSSILG AINFMTTTKN LRSSSISLEH MSLFVWTVFV 120 PPLSTMGHPG SSVDLAIFSL HSAGVSSILG AINFMTTTKN LRSSSISLEH MSLFVWTVFV 120 PPLSTMGHPG SSVDLAIFSL HSAGVSSILG AINFMTTTKN LRSSSISLEH MSLFVWTVFV 120 PPLSTMGHPG SSVDLAIFSL HCAGASSILG AINFMTTTKN LRSSSISLEH MSLFVWTVFV 120 PPISTMGHPG SSVDLAIFSL HCAGASSILG AINFMTTTKN LRSSSISLEH MSLFVWTVFV 120 PPLSTMGHPG SSVDLAIFSL HCAGASSILG AINFMTTTKN LRSSSISLEH MSLFVWTVFV 120 PPLSTMGHPG SSVDLAVFSL HCAGVSSILG AINFMTTTKN LRSSSISLEH MSLFVWTVFV 120 PPLSTMGHPG SSVDLAIFSL HCAGVSSILG AINFMTTTKN LRSSSISLEH MSLFVWTVFV 120 PPLSTMGHPG SSVDLAIFSL HCAGVSSILG AINFMTTTKN LRSSSISLEH MSLFVWTVFV 120 PSLSTMGHPG SSVDLAIFSL HCAGVSSILG AINFMTTTKN LRSSSISLEH MSLFVWTVFV 120 PPLSTMGHPG SSVDLAIFSM HCAGVSSILG AINFMTTTKN LRSSSISLEH MSLFVWTVFV 120 PPLSTMGHPG SSVDLAIFSL HCAGVSSILG AINFMTTTKN LRSSSISLEH MSLFVWTVFV 120 PPLSTMGHPG SSVDLAIFSL HCAGVSSILG AINFMTTTKN LRSSSISLEH MSLFVWTVFV 120 PPLSTLGHPG SSVDLAIFSL HCAGVSSILG AINFMTTTKN LRSSSISLEH MSLFVWTVFV 120

TVFLLILSLP VLAGAITMLL TDRNLNTSFF DPSTGGNPLI YOHLFWFFGH PEVYILILPA 180 TVFLLILSLP VLAGAITMLL TDRNLNTSFF DPSTGGNPLI YQHLFWFFGH PEVYILILPA 180 TVFLLILSLP VLAGAITMLL TDLNLNTSFF DPSTGGNPLI YQHLFWFFGH PEVYILILPA 180 TVFLLILSLP VLAGAITMLL TDRNLNTSFF DPSTGGNPLI YQHLFWFFGH PEVYILILPX 180 TVFLLILSLP VLAGAITMLL TDRNLNTSFF DPSTGGNPLI YQHLFWFFGH PEVYILILPA 180 TVFLLILSLP VLAGAITMLL TDRNLNTSFF DPSTGGNPLI YQHLFWFFGH PEVYILILPA 180 TVFLLILSLP VLAGAITMLL TDRNLNTSFF DPSTGGNPLI YOHLFWFFGH PEVYILILPA 180 TVFLLILSLP VLAGAITMLL TDRNLNTSFF DPSTGGNPLI YQHLFWFFGH PEVYILILPA 180 TVFLLILSLP VLAGAITMLL TDRNLNTSFF DPSTGGNPLI YQHLFWFFGH PEVYILILPA 180 TVFLLILSLP VLAGAITMLL TDRNLNTSFF DPSTGGNPLI YQHLFWFFGH PEVYILILPA 180 TVFLLILSLP VLAGAITMLL TDRNLNTSFF DPSTGGNPLI YOHLFWFFGH PEVYILILPA 180 TVFLLILSLP VLAGAITMLL TDRNLNTSFF DPSTGGNPLI YOHLFWFFGH PEVYILILPA 180 TVFLLILSLP VLAGAITMLL TDRNLNTSFF DPSTGGNPLI YQHLFWFFGH PEVYILILPA 180 TVFLLILSLP VLAGAITMLL TDRNLNTSFF DPSTGGNPLI YQHLFWFFGH PEVYILILPA 180 TVFLLILSLP VLAGAITMLL TDRNLNTSFF DPSTGGIPLI YHHLF_.... $\ldots \ldots \ldots$

FGIISQSSLY LTGKKEVFGS LGMVYAILSI GLIGCVVWAH HMYTVGMDLD SRAYFTAATM 240 FGIISOSSLY LTGKKEVFGS LGMVYAILSI GLIGCVVWAH HMYTVGMDLD SRAYFTAATM 240 FGIISQSSLY LTGKKEVFGS LGMVYAILSI GLIGCVVWAH HMYTVGMDLD SRAYFTAATM 240 FGIISQSSLY LTGKKEVFGS LGMVYAILSI GLIGCVVWAH HMYTVGMDLD SRAYFTAATM 240 FGIISOSSLY LTGKKEVFGS LGMVYAILSI GLIGCVVWAH HMYTVGMDLD SRAYFTAATM 240 FGIISQSSLY LTGKKEVFGS LGMVYAILSI GLIGCVVWAH HMYTVGMDLD SRAYFTAATM 240 FGIISQSSLY LTGKKEVFGS LGMVYAILSI GLIGCVVWAH HMYTVGMDLD SRAYFTAATM 240 FGIISOSSLY LTGKKEVFGS LGMVYAILSI GLIGCVVWAH HMYTVGMDLD SRAYFTAATM 240 FGIISOSSLY LTGKKEVFGS LGMVYAILSI GLIGCVVWAH HMYTVGMDLD SRAYFTAATM 240 FGIISQSSLY LTGKKEVFGS LGMVYAILSI GLIGCVVWAH HMYTVGMDLD SRAYFTAATM 240 FGIISQSSLY LTGKKEVFGS LGMVYAILSI GLIGCVVWAH HMYTVGMDLD SRAYFTAATM 240 FGIISOSSLY LTGKKEVFGS LGMVYAILSI GLIGCVVWAH HMYTVGMDLD SRAYFTAATM 240 FGIISOSSLY LTGKKEVFGS LGMVYAILSI GLIGCVVWAH HMYTVGMDLD SRAYFTAATM 240 FGIISQSSLY LTGKKEVFGS LGMVYAILSI GLIGCVVWAH HMYTVGMDLD SRAYFTAATM 240

VIAVPTGVKV FSWLATLFGM KMVFOPX 267 VIAVPTGVKV FSWLATLFGM KMVFQPX 267 VIAVPTGVKV FSWLATLFGM KMVFOPX 267 VIAVPTGVKV FSWLATLFGM KMVFQPX 267 VIAVPTGVKV FSWLATLFGM KMVFOPX 267 VIAVPTGVKV FSWLATLFGM KMVFQPX 267 VIAVPTGVKV FSWLATLFGM KMVFQPX 267 VIAVPTGVKV FSWLATLFGM KMVFOPX 267 VIAVPTGVKV FSWWATLFGM KMVFOPX 267 VIAVPTGVKV FSWLATFFGM KMVFQPX 267 VIAVPTGVKV FSWLATLFGM KMVFQPX 267 VIAVPTGVKV FSWLATLFGM KMVFOPX 267 VIAVPTGVKV FSWLATLFGM KMVFOPX 267 VIAVPTGVKV FSWLATLFGM KMVFQPX 267

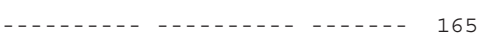


(Fig. 1) and the fact that all analysed fish, irrespective of sample origin, showed consistent identical parasitological and pathological findings, suggest that all observed RVS-affected fish reported from different areas would reflect a similar condition.

Anisakis spp. in wild salmon is not an unusual finding, but is RVS a 'real emerging' condition or is it a newly detected condition (apparent emergence) due to location of the larvae and/or apparent higher prevalence in the host population? Major concerns were expressed by fishery managers and anglers regarding the impact of RVS on the fish and whether it could induce mortality or prevent spawning by any type of 'obstruction' of the genital area. Interestingly, the vent and urogenital papilla region rarely form part of any histopathological assessment, and this was reflected by the scarcity of bibliography thoroughly describing the region. Histological assessment of both male and female brood fish showed no evidence of obstruction or blocking of the genital cavity or pores with the parasites. Larvae could occasionally be seen within the lumen, but were likely to be migrating or pushed from the terminal portion of the abdominal cavity during stripping. However, larvae were responsible for some of the damage recorded in the vent and urogenital papilla of the analysed brood fish. Assisted spawning involves a certain degree of handling, including the compression of the vent when fish are manually stripped. Due to the pressure from the increased amount of cells and the 'masses of harder tissue' of encapsulated and non-encapsulated larvae in the area, tissue damage, including capillary breakdown, haemorrhage and a degree of inflammation, was observed. No material for 'comparative purposes' is available but a baseline level of tolerable and repairable damage is certainly expected after stripping. However, the most conclusive evidence of non-compromised spawning was a successful season of wild salmon under hatchery intervention in 2007.

An issue of public concern was whether RVS could affect or be linked to farmed Atlantic salmon. This syndrome was not reported in farmed fish and was restricted to wild Atlantic salmon. Previous studies have shown that anisakids are rare in farmed fish. In Japan, Norway and the USA, farmed salmonids (Atlantic salmon Salmo salar, coho salmon Oncorhynchus kisutch, Chinook salmon O. tshawytscha and rainbow trout O. mykiss) did not harbour Anisakis spp. in the viscera or muscle (Deardorff \& Kent 1989, Inoue et al. 2000, Lunestad 2003), or the infection was very low (Inoue et al. 2000). Similarly, studies in Canada by Marty (2008) showed that by using Anisakis spp. prevalence in the viscera as an estimate of the parasite prevalence in the edible tissues, the risk ratio of Anisakis spp. in commercial farmed products was 570 times lower than in wild salmon. Despite extensive official surveillance, there are no reports of RVSaffected farmed salmon in Scotland; hence, the present study shows no direct link of aquaculture with RVS.

The reported prevalence of Anisakis simplex in wild Atlantic salmon varies from 65 to $100 \%$ in the North, West and East Atlantic (Huss \& Embarek 2003), while in the Puget Sound, North Pacific Ocean, 100\% of sockeye salmon Oncorhynchus nerka caught during their spawning migration were found to be infected (Deardorff \& Kent 1989). However, a surprisingly limited amount of work has been carried out on Anisakis spp. infection in salmon compared to that on other commercially exploited fish such as Atlantic cod Gadus morhua, herring Clupea harengus, haddock Melanogrammus aeglefinus, mackerel Scomber scombrus, monkfish Lophius piscatorius and whiting Merlangius merlangus. Clear differences have been reported between the site location of anisakids species and their host and between host species (Smith 1984, Wootten \& Jones 2007). Studies have shown that Anisakis spp. L3 tend to be more prevalent in the viscera or the musculature depending on the host's diet - more in the body cavity of euphausiid-feeding fish such as herring and mackerel but distributed throughout tissues among piscivorous hosts such as whiting and cod (Smith 1984). However, studies in Pacific chum salmon $O$. keta showed that $87 \%$ of the larval load was recorded in the musculature (Deardorff \& Kent 1989). Similarly, a study in the same species in Japan and the Bering Sea confirmed that $A$. simplex larvae were consistently more abundant in the skeletal muscle around the body cavity than in the visceral organs (Sugawara et al. 2004). These data seem to suggest that for salmonids at least, muscle infestation is more likely to occur than in other Anisakis spp. hosts. This is consistent with the present study data from RVS-affected wild Atlantic salmon, where a novel non-viscera location, the vent, and the very closely associated dorso-lateral musculature, proved to be able to harbour numerous larvae. To the best of our knowledge, other than for the previous preliminary reports for Scotland (Noguera et al. 2008) and recently, the report of RVS from England and Wales (Beck et al. 2008), Anisakis spp. have not been reported as being highly localised in a particular nonvisceral region such as the vent, invading a discrete area at a high intensity. In the present study, although the data were qualitative and not non-quantitative, they showed no relationship between larval load in the body cavity and viscera, and the presence and numbers seen in the vent area. All analysed fish had low to moderate numbers of larvae in the body cavity but the numbers and extent of the lesion in the vent varied considerably from fish to fish. Moreover, it was observed in the present study that some of the fish 
sampled as normal reference and negative fish collected later in the season were also positive for parasites in the vent area (data not shown). It seems unlikely that if present for as long as Anisakis spp. has been reported in the North Sea, RVS would have not been described. However, as the vent is frequently neglected during routine investigation, it is possible that the condition have been overlooked and underreported until prominent lesions, such as the ones reported here, became conspicuous. This 'hyper-infestation' of the vent is therefore considered a novel site (as defined by Crompton 1973) for the parasite, and so far only reported for Atlantic salmon. The described observations and tissue changes in the vent-urogenital papilla constitute a particular type of lesion that can be considered pathognomonic, if not for the presence of the parasite, then for the condition described here as RVS.

Because of the novel site of infection and extent of tissue damage, it was hypothesised that the nematodes in this region might represent a different species of Anisakis from that normally found in the viscera and body cavity of wild Atlantic salmon. A report by Beck et al. (2008) associated the condition in England and Wales with $A$. simplex sensu lato, although the method for parasite identification was not reported. Molecular analysis in the present study based on ITS sequence identified the nematodes in the body cavity and vent as A. simplex s.s. based on previously defined diagnostic nucleotides and RFLP patterns. However, polymorphism was seen at a number of additional positions within some individuals analysed from both cavity and vent. Heterogeneous positions have been observed previously in the ITS rDNA of Anisakis spp. specimens, representing potential hybridisation events between A. simplex s.s. and A. pegreffii. The heterogeneity was observed at those sites diagnostic for each species. The heterogeneity was only observed in areas where sympatric coexistence occurred (Abollo et al. 2003, Farjallah et al. 2007). ITS sequences from anisakids isolated from Baltic Sea herring had a $\mathrm{T}$ at position 173, whereas other A. simplex s.s. possessed a C. These herring anisakids could represent the second 'variant' in a hybrid situation; however, they did not display the corresponding polymorphic nucleotides at the other positions observed in anisakids from RVS salmon. In addition, analysis of cloned ITS identified 3 different types of ITS variants, and not 2 as might be expected from a hybrid situation. The relative peak heights of the 2 nucleotides at the polymorphic sites did vary in amplitude between individuals (data not shown). It is worth noting that an anisakid sequence from onion-eye grenadier from east Greenland submitted to the NCBI GenBank sequence database in 2009 (Accession no. GQ131690) displayed an N at position
173 and a C/T polymorphism at 305, corresponding to the polymorphisms seen in some anisakids from RVS salmon. It is not clear from current sequence data whether the polymorphisms arose from hybridisation events (recent or distant) between different species, or between strains of $A$. simplex, or through intraspecific variation occurring naturally within the rDNA repeats. The level of variation in the ITS region can be very low even between defined Anisakis spp. (Nadler et al. 2005); therefore, even 2 nucleotide differences could indicate the emergence of a new Anisakis species/subspecies, differing in its life history. cox1 mtDNA was also sequenced from nematodes found in cavity and vent. The $\operatorname{cox} 1 \mathrm{mtDNA}$ is considered to evolve faster than rDNA (Blouin et al. 1998), but again, no clear differences in the cox1 sequence were observed between the vent larvae and those from the body cavity, and between individuals with polymorphisms in their ITS rDNA. There is insufficient data to comment on whether the 2 conserved nucleotide/amino acid differences in the cox1 sequence between anisakid specimens infecting RVS salmon and those infecting herring populations around the British Isles (Cross et al. 2007) is due to species or population differences. The latter individuals were collected from different hosts, with potentially different migration patterns and at a different time period.

While we had initially looked for differences between Anisakis spp. specimens infecting cavity and vent, it may be that the specimens characterised from RVS-affected salmon are variants which invade the cavity and vent rather than cavity alone, and as such, clear differences between sites of infection within a host may not be observed. More widespread sampling of anisakids from salmon with and without RVS, and/or infection experiments with different anisakid variants may provide an answer.

The mechanisms that determine the occurrence and distribution of Anisakis spp. in the northeast Atlantic ecosystem are largely unknown, but it has been proposed that Anisakis spp. in these waters occurs in fish from 2 ecologically different environments: the pelagic/oceanic and the benthic/coastal ecosystem (Levsen 2007). As anadromous fish, salmon are known to undertake extensive marine-feeding migrations (Mills 1991), and so they will inhabit both environments at different points during their sea life. Between the time smolts leave the river until mature fish return for spawning one or more years later, it is not known precisely when infestation of the vent takes place. However, preliminary observations from the present study showed different sizes of larvae observed macroscopically and histologically, some still migrating. Together with the observations of an acute inflammatory reaction in the early summer sam- 
ples, this seem to indicate that the vent as a specific localisation had been affected during the last period when salmon would still be feeding. It should be stressed that the presence of different sizes of L3 as well as both encapsulated and non-encapsulated parasites could well reflect different times of ingestion and from a different prey, but as fish accumulate the parasite over time, it could also reflect the predation on other highly infected fish, resulting in the salmon acquiring a wide range of Anisakis spp. stages from a single meal. Histological assessment showed that the summer grilse had apparently more non-encapsulated larvae and signs of ongoing migration, reflecting a relatively recent infection. Conversely, analysis of brood fish in freshwater for several months showed a complete healing of external lesions and characteristic signs of tissue reaction such as granulomatous encapsulation and increased pigmented cell, differences likely reflecting time after settlement of larvae. Moreover, in a parallel study analysing the prevalence of the syndrome, it was noted that the following season (2008) showed a higher prevalence of moderate-tosevere RVS cases among the 2-sea-winter fish (C. Todd pers. comm.). This suggests that in the development of the syndrome, neither the mere fact of the presence of larvae (some obviously non-affected fish also harboured larvae in the vent), nor the stage at which salmon are infected are the most significant factors; what is most significant is the impact resulting from the cumulative effect of the high numbers of larvae within such a discrete volume of tissues (approx. 2 to $3 \mathrm{~cm}^{3}$ ).

Fish collected in the sea or in estuarine waters (Strathy Point and North Esk) showed a strongly EGCdominated inflammatory reaction; ECG is a type of cell considered to be analogous to the mast cells in helminth-infected mammals and birds (Reite 1997). The significance of this observation is not entirely clear, as it is possible that, rather than representing a specific reaction to Anisakis spp., they might reflect a physiological state of the fish. Persistent inflammation and massive recruitment of granular cells in the intestinal tissue of helminth-infested salmonids has been previously described (Murray 1972, Sharp et al. 1989, Ferguson 2006), but similarly, a massive degranulation of EGCs followed by an acute inflammatory reaction can be induced by the injection of hydrocortisone (Reite 1997). The histological analysis of samples from fish that had been in the freshwater for weeks or months showed that EGCs were not predominant anymore or were completely absent. Hence, the initial EGC-dominated inflammatory response, observed particularly in the early summer fish, may reflect at least partially the physiological stage of the fish (reproductive migration) rather than a specific reaction to the parasite.
While it was possible to hypothesise that a spontaneous change has occurred in Anisakis spp., it is more likely that the sudden North Atlantic-wide emergence of RVS could be a sign of ocean-scale changes in the environment, reflecting the North Atlantic occurrence of RVS. In host-parasite interactions, models and empirical studies of co-evolution assume that host resistance and parasitic infectivity are genetically based, though even in such cases non-genetic physiological or environmental influences can also alter host susceptibility (Dybdahl \& Krist 2004). A factor valid at the ocean scale (and above), is water temperature, which can influence both parasite cycles and the host. Warming has been pronounced in the North Atlantic waters, with Scottish sea-surface temperatures rising 0.2 to $0.6^{\circ} \mathrm{C}$ per decade (Baxter et al. 2008), including in the foraging areas exploited by salmon (Todd et al. 2008). Seven of the 10 warmest years have occurred in the last decade, and 2006 was the second warmest year in UK coastal waters since records began in 1870 (Hughes 2006, Hughes \& Holliday 2006, 2007, Hughes et al. 2008). Climate and climate variability affecting all components of the host-pathogen-environment triad have already been implicated as an important factor in the emergence of disease (Kutz et al. 2004). More generally, the $15^{\circ} \mathrm{C}$ summer isotherm has moved $330 \mathrm{~km}$ north in the last $17 \mathrm{yr}$ (McMahon \& Hays 2006), and studies by Beaugrand et al. (2008) in the North Atlantic showed that regions in which biome boundaries shifts occur are more vulnerable to the impact of climate change. There is a general tendency for parasitic infections to increase with temperature (Farjallah et al. 2006), and rising water temperatures have been reported to directly influence the incidence of disease threats from parasitic infections (Harvell et al. 1999, 2002, Hakalahti et al. 2006), particularly in temperate regions where transmission is strongly related to 'windows' of suitable temperature ranges. Increased infection pressure (as has apparently occurred with salmon) due to warming waters has been reported for metazoans (Argulus coregoni and Diplostomum spathacum usually found in fish culture) in Finland (Hakalahti et al. 2006). Infestation with Anisakis spp. of salmon or other fish predators may be particularly sensitive to temperature because infestation occurs via consumption of other infested intermediate hosts. There have been major changes in the distribution of plankton communities and fish species in the North Atlantic region (McMahon \& Hays 2006), and recently biome boundaries movements due to climate warming have been suggested to possibly induce prey to follow alongside (Beaugrand et al. 2008). Another concomitant factor is fishing, although separating a response to climate variability from fishing practices has been difficult (Drinkwater et al. 2003). 
Due to spatial and temporal differences, salmon might have been presented with reduced availability in prey and the need to compete (temporary absence of a given prey) or variability (different feeding options), leading to a shift in their diet, hence exposing them to increased Anisakis spp. loads. Interestingly, a decline in Atlantic salmon abundance has been reported for the last 3 decades, and warming seawaters of the northeast Atlantic have been associated with detrimental effects for this species. Todd et al. (2008) reported that both survival and growth have been impacted after analysis of 2 independent $14 \mathrm{yr}$ time series, showing evidence of recent climate-driven changes in the eastern North Atlantic pelagic ecosystem. Finally, human allergic and gastro-allergic reactions to A. simplex were reported to have dramatically increased in Spain between 1995 and 2005 (Del Rey Moreno et al. 2006) and could reflect changes in culinary and feeding habits or improved diagnosis; however, it could also reflect, as reported by Valero et al. (2006), a real general increase in the prevalence of anisakid parasites in virtually all the wide range of fish hosts.

Unfortunately, establishing the specific implications of environmental changes on particular groups of interest will always be problematic, as historic data for comparative purposes are lacking. RVS might represent the observable final outcome of a chain of linked events where the increase in Anisakis spp. loads in salmon has only been highlighted by the conspicuous external lesions given the unique location of the parasite. The particular reasons for the dramatic increase in RVS observations in 2007 are as yet unclear; however, why the parasite is concentrated in the vent is a realistic area for further research. The consistent presence and parasite loads suggest the vent is unlikely to constitute an 'accidental location' and any advantage to the parasite on infesting the vent has yet to be elucidated.

Acknowledgements. We are especially grateful to John Webb for continual support through constructive discussions and comments, as well as for assistance with and provision of samples. Alistair McDonald, Andrea Warwick, Katy Urquhart and Sonia Duguid helped with the collection of samples, and David Stewart and Ian McLaren provided useful information on previous observations, the anglers' point of view or current reports. Thanks are extended to Sandy Murray for his constructive review of the manuscript.

\section{LITERATURE CITED}

Abollo E, Gestal C, Pascual S (2001) Anisakis infestation in marine fish and cephalopods from Galician waters: an updated perspective. Parasitol Res 87:492-499

Abollo E, Paggi L, Pascual S, D'Amelio S (2003) Occurrence of recombinant genotypes of Anisakis simplex s.s. and Anisakis pegreffii (Nematoda: Anisakidae) in an area of sympatry. Infect Genet Evol 3:175-181

Audicana MT, Ansotegui IJ, Fernadez de Corres L, Kennedy MW (2002) Anisakis simplex: dangerous-dead and alive? Trends Parasitol 18:20-25

Bakke TA, Harris PD (1998) Diseases and parasites in wild Atlantic salmon (Salmo salar) populations. Can J Fish Aquat Sci 55:247-266

Baxter JM, Buckley PJ, Wallace CJ (eds) (2008) Marine climate change impacts annual report card 2007-2008, summary report. Marine Climate Change Impacts Partnership (MCCIP), Lowestoft. www.mccip.org.uk/arc/2007/default. htm

Beaugrand G, Edwards M, Brander K, Luczak C, Ibanez F (2008) Causes and projections of abrupt climate-driven ecosystem shifts in the North Atlantic. Ecol Lett 11: 1157-1168

Beck M, Evans R, Feist SW, Stebbing P, Longshwa M, Harris E (2008) Anisakis simplex sensu lato associated with red vent syndrome in wild adult Atlantic salmon Salmo salar in England and Wales. Dis Aquat Org 82:61-65

Berland B (1961) Nematodes from some Norwegian marine fishes. Sarsia 2:1-50

> Blouin MS, Yowell CA, Courtney CH, Dame JB (1998) Substitution bias, rapid saturation, and the use of mtDNA for nematode systematics. Mol Biol Evol 15:1719-1727

Bruno DW, Nowak B, Elliott DG (2006) Guide to the identification of fish protozoan and metazoan parasites in stained tissue sections. Dis Aquat Org 70:1-36

Crompton DWT (1973) The sites occupied by some parasitic helminths in the alimentary tract of vertebrates. Biol Rev Camb Philos Soc 48:27-83

> Cross MA, Collins C, Campbell N, Watts PC and others (2007) Levels of intra-host and temporal sequence variation in a large COI sub-units from Anisakis simplex sensu stricto (Rudolphi 1809) (Nematoda: Anisakisdae): implications for fisheries management. Mar Biol 151:695-702

Cunningham CO, Mo TA, Collins CM, Buchmann K, Thiery R, Blanc G, Lautraite A (2001) Redescription of Gyrodactylus teucjis Lautraite, Blanc, Thiery, Daniel \& Vigneulle, 1999 (Monogenea: Gyrodactylidae); a species identified by ribosomal RNA sequence. Syst Parasitol 48:141-150

D'Amelio S, Mathiopoulus KD, Santos C, Pugachev ON, Webb SC, Picanço M, Paggi L (2000) Genetic markers in ribosomal DNA for the identification of members of the genus Anisakis (Nematoda: Ascaridoidea) defined by polymerase chain reaction-based restriction fragment length polymorphism. Int J Parasitol 30:223-226

> Davey JT (1971) A revision of the genus Anisakis Dujardin, 1845 (Nematoda: Ascaridida). J Helminthol 45:51-72

> Deardorff TL, Kent ML (1989) Prevalence of larval Anisakis simplex in pen-reared and wild-caught salmon (Salmonidae) from Puget Sound, Washington. J Wildl Dis 25: 416-419

> Del Rey Moreno A, Valero A, Mayorga C, Gómez B and others (2006) Sensitization to Anisakis simplex s.1. in a healthy population. Acta Trop 97:265-269

Drinkwater, KF, Belgrano A, Borja A, Conversi A and others (2003) The response of marine ecosystems to climate variability associated with the North Atlantic oscillation. Climatic significance and environmental impact. Geophys Monogr 134:211-234

- Dybdahl MF, Krist AC (2004) Genotypic vs. condition effects on parasite-driven rare advantage. J Evol Biol 17:967-973

- Farjallah SF, Slimane BB, Blel H, Amor A, Said K (2006) Anisakid parasites of two forkbeards (Phycis blennoides and Phycis phycis) from the eastern Mediterranean coasts in Tunisia. Parasitol Res 100:11-17 
Farjallah S, Busi M, Ben Slimane B, Ould Mahjoub M, Paggi L, Said K, D'Amelio S (2007) Occurrence of Anisakis spp. from North African coasts of Mediterranean Sea and east Atlantic Ocean. Parassitologia 49:218

Ferguson HW (2006) Systemic pathology of fish, 2nd edn. Scotian Press, London

Hakalahti T, Karvonen A, Valtonen ET (2006) Climate warming and disease risks in temperate regions-Argulus coregoni and Diplostomum spathaceum as case studies. J Helminthol 80:93-98

Hall TA (1999) BioEdit: a user-friendly biological sequence alignment editor and analysis program for Windows 95/98/NT. Nucleic Acids Symp Ser 41:95-98

- Harvell CD, Kim K, Burkholder JM, Colwell RR and others (1999) Emerging marine diseases - climate links and anthropogenic factors. Science 285:1505-1510

Harvell CD, Mitchell CE, Ward JR, Altizer S, Dobson AP, Ostfeld RS, Samuel MD (2002) Climate warming and disease risks for terrestrial and marine biota. Science 296: 2158-2162

Helgason S, Slavko HB, Kristmundsson A (2008) Red vent syndrome in wild Atlantic salmon (Salmo salar) in Icelandic waters. Int Conf Fish Dis Fish Immunol, 6-9 September, 2008, Reykjavik, Session 4: Parasitology, Poster 7 , p 67

Hodneland K, Endresen C (2006) Sensitive and specific detection of Salmonid alphavirus using real-time PCR (TaqMan). J Virol Methods 131:184-192

Hughes S (2006) Impacts of climate change on sea temperature. In: Buckley PJ, Dye SR, Baxter JM (eds) Marine climate change impacts annual report card 2006. Marine Climate Change Impacts Partnership (MCCIP), Lowestoft. www.mccip.org.uk/arc/2006/temp1.htm

Hughes SL, Holliday NP (2006) The ICES report on ocean climate 2005. CLIVAR Exch 11:26-27

Hughes SL, Holliday NP (2007) ICES report on ocean climate 2006. ICES Coop Res Rep 289:1-55

Hughes SL, Holliday NP, Beszczynska-Möller A (2008) ICES report on ocean climate 2007. ICES Coop Res Rep 291: $1-64$

Huss HH, Embarek PKB (2003) Parasites. In: Huss HH, Ababouch L, Gram L (eds) Assessment and management of seafood safety and quality. FAO Fish Tech Pap 444: $60-70$

Inoue K, Oshima SL, Hirata T, Kimura I (2000) Possibility of anisakid larvae infection in farmed salmon. Fish Sci 66:1049-1052

Johnsen JO, Jensen JA (1991) The Gyrodactylus story in Norway. Aquaculture 98:289-302

Kent ML, Fournie JW (1993) Importance of marine fish diseases - an overview. In: Couch JA, Fournie JW (eds) Pathobiology of marine estuarine organisms. CRC Press, Boca Raton, FL, p 1-24

Kim KH, Eom KS, Park JK (2006) The complete mitochondrial genome of Anisakis simplex (Ascaridida: Nematoda) and phylogenetic implications. Int J Parasitol 36:319-328

Kutz SJ, Hoberg EP, Nagy J, Polley L, Elkin B (2004) Emerging parasitic infections in Arctic ungulates. Integr Comp Biol 44:109-118

Levsen A (2007) Modelling the life cycle of the Anisakis simplex complex in the Northeast Atlantic. In: Levsen A (ed) Report from a Nordic/northern European scientific workshop, 30 Nov-1 Dec 2006, Bergen. NIFES, Bergen, p 60-61

Lorensen E (1993) The importance of the brand of the beef extract in relation to growth of Flexibacter psychrophilus in Anacker \& Ordal medium. Bull Eur Assoc Fish Pathol
13:64-65

Lunestad BT (2003) Absence of nematodes in farmed Atlantic salmon (Salmo salar L.) in Norway. J Food Prot 66:122-124

Mackie MD, Arkwright JA, Pryce-Tannant TE, Mottram JC, Johnston WD, Menzies WJM (1933) Second report of the Furunculosis Committee. HSMO, Edinburgh

- Marty GD (2008) Anisakid larva in the viscera of a farmed Atlantic salmon (Salmo salar). Aquaculture 279:209-210

> Mattiucci S, Nascetti G (2006) Molecular systematics, phylogeny and ecology of anisakid nematodes of the genus Anisakis Dujardin, 1845: an update. Parasite 13:99-113

Mattiucci S, Nascetti G (2008) Advances and trends in the molecular systematics of anisakid nematodes, with implications for their evolutionary ecology and host-parasite co-evolutionary processes. Adv Parasitol 66:47-148

> Mattiucci S, Nascetti G, Cianchi R, Paggi L and others (1997) Genetic and ecological data on the Anisakis simplex complex, with evidence for a new species (Nematoda, Ascaridoidea, Anisakidae). J Parasitol 83:401-416

> Mattiucci S, Abaunza P, Ramadori L, Nascetti G (2004) Genetic identification of Anisakis larvae in European hake from Atlantic and Mediterranean waters for stock recognition. J Fish Biol 65:495-510

Mattiucci S, Nascetti G, Dailey M, Webb SC, Cianchi R, Bullini L (2005) Evidence for a new species of Anisakis Dujardin, 1845: morphological description and genetic relationships between congeners (Nematoda: Anisakidae). Syst Parasitol 61:157-171

McMahon CR, Hays GC (2006) Thermal niche, large-scale movements and implications of climate change for a critically endangered marine vertebrate. Glob Change Biol 12:1330-1338

Mills D (1991) Ecology and management of Atlantic salmon. Springer, New York

Moravec F (2004) Some aspects of the taxonomy and biology of dracunculoid nematodes parasitic in fishes: a review. Folia Parasitol 51:1-13

Murray YM (1972) Immediate hypersensitivity effector mechanisms. II. In vivo reactions. In: Soulsby EJL (ed) Immunity to animal parasites. Academic Press, New York, p 155-199

Nadler SA, D'Amelio S, Dailey MD, Paggi L, Siu S, Sakanari JA (2005) Molecular phylogenetics and diagnosis of Anisakis, Pseudoterranova and Contracaecum from Northern Pacific marine mammals. J Parasitol 91: 1413-1429

> Nascetti G, Paggi L, Orecchia P, Smith JW, Mattiucci S, Bullini L (1986) Electrophoretic studies on the Anisakis simplex complex (Ascaridida: Anisakidae) from the Mediterranean and North-East Atlantic. Int J Parasitol 16:633-640

Noguera P, Bruno DW, Pert CC, Webb J (2008) Red vent syndrome (RVS) in wild Atlantic salmon: an update on research and monitoring in Scotland. Atl Salmon Trust J Summer:25-27

OIE (World Organisation for Animal Health) (2006) Manual of diagnostic tests for aquatic animals, 5 th edn. OIE, Paris

Orecchia P, Pagg IL, Mattiucci S, Nascetti G, Smith JW, Bullini L (1986) Electrophoretic identification of larvae and adults of Anisakis (Ascaridida: Anisakidae). J Helminthol 60:331-339

Pontes T, D'Amelio S, Costa G, Paggi L (2005) Molecular characterisation of larval anisakid nematodes from marine fishes of Maderia by a PCR-based approach, with evidence for a new species. J Parasitol 91:1430-1434

Posada D, Crandall KA (1998) Testing the model of DNA substitution. Bioinformatics 14:817-818 
Reite OB (1997) Mast cells/ eosinophilic granule cells of salmonids: staining properties and responses to noxious agents. Fish Shellfish Immunol 7:567-584

Roberts RJ (1993) Ulcerative dermal necrosis (UDN) in wild salmonids. Symposium on the pathological conditions of wild salmonids, Aberdeen, Scotland, UK, May 1992. Fish Res 17:3-14

Scottish Executive (2004) The economic impact of game and coarse angling in Scotland. Scottish Executive, www. scotland.gov.uk/Publications/2004/06/19506/38879

Sharp GJE, Pike AW, Secombes CJ (1989) The immune response of wild rainbow trout, Salmo gairdneri Richardson, to naturally acquired plerocercoid infection of Diphillobothrium dendriticum (Nitzsch, 1824) and D. ditremum (Creplin, 1825). J Fish Biol 35:781-793

Smith JW (1984) The abundance of Anisakis simplex L3 in the body cavity and flesh of marine teleosts. Int J Parasitol 14:491-495

Smith JW, Wootten R (1978) Anisakis and anisakiasis. Adv Parasitol 16:93-163

Smith JW, Wootten R (1984) Anisakis larvae ('herringworm') (Nematoda) in fish. In: Sinderman CJ (ed) Fiches d'identification des maladies et parasites des poissons, crustaces et mollusques, Fiche no. 7. ICES, Copenhagen, p 1-5

Sugawara Y, Urawa S, Kaeriyama M (2004) Infection of Anisakis simplex (Nematoda: Anisakidae) larvae in chum salmon (Oncorhynchus keta) in the North Pacific Ocean, Bering Sea, and a river of Hokkaido. NPAFC Doc 791. Hokkaido Tokai University, Sapporo

Swofford DL (1999) PAUP*: phylogenetic analysis using parsimony ( ${ }^{*}$ and other methods), V 4.0. Sinauer Associates, Sunderland, MA

Todd CD, Hughes SL, Marshall CT, MacLean JC, Lonergan

Editorial responsibility: Sven Klimpel,

Düsseldorf, Germany
ME, Biuw EM (2008) Detrimental effects of recent ocean surface warming on growth condition of Atlantic salmon. Glob Change Biol 14:958-970

> Umehara A, Kawakami Y, Araki J, Uchida A (2007) Molecular identification of the etiological agent of the human anisakiasis in Japan. Parasitol Int 56:211-215

> Valentini A, Mattiucci S, Bondanelli P, Webb SC, MignucciGiannone AA, Colom-Llavina MM, Nascetti G (2006) Genetic relationships among Anisakis species (Nematoda: Anisakidae) inferred from mitochondrial cox2 sequences, and comparison with allozyme data. J Parasitol 92: 156-166

Valero A, Paniagua MI, Hierro I, Diaz V, Valderrama MJ, Benitez R, Adroher FJ (2006) Anisakid parasites of two forkbeards (Phycis blennoides and Phycis phycis) from the Mediterranean coasts of Andalucia (southern Spain). Parasitol Int 55:1-5

Wootten R, Cann DC (1980) Round worms in fish. Torry advisory note no. 80. Ministry of Agriculture, Fisheries and Food, Torry Research Station, Aberdeen

Wootten R, Jones A (2007) Anisakis - where does it go in the fish? In: Levsen A (ed) Modelling the life cycle of the Anisakis simplex complex in the Northeast Atlantic. Report from a Nordic/northern European scientific workshop, 30 Nov-1 Dec, 2006, Bergen. NIFES, Bergen, p 51-54

Zaffiro A, Cadoni S, Giani M, Guerr EC and others (2002) Ipersensibilità ad Anisakis simplex: casistica di tre anni (1999-2001). G Ital Allergol Immunol Clin 12:140-146

Zhu X, Gasser RB, Podolska M, Chilton NB (1998) Characterisation of anisakid nematodes with zoonotic potential by nuclear ribosomal DNA sequences. Int J Parasitol 28: 1911-1921

Submitted: December 22, 2008; Accepted: September 10, 2009 Proofs received from author(s): November 25, 2009 